\title{
Az etika (újbóli) térnyerése az üzleti folyamatokban - A haszonelvűségtől a tudatos fogyasztóig (irodalmi áttekintés)
}

\author{
Return of Ethics into Business Activities - From \\ Utilitarianism to Conscious Consumers (review)
}

\section{E. TóTH}

Debreceni Egyetem, Gazdaságtudományi Kar, Világgazdasági és Nemzetközi Kapcsolatok Intézet, toth.eszter@econ.unideb.hu

Absztrakt. A gazdaságtudomány kiindulópontja a haszonmaximalizáló ember, aki preferenciái mentén haladva olyan racionális döntést igyekszik hozni, amely a legelőnyösebb helyzetet eredményezi számára. A tervezést megkönnyítve számos modellt használnak a közgazdaságtanban, amely fenti állítást axiómaként kezeli. A valós folyamatokat és motivációkat elemezve azonban nem hagyhatjuk figyelmen kívül a gazdasági szereplők emberi oldalát, erkölcsi vélekedést sem. A gazdasági etika mindig is jelen volt az üzleti életben, jóllehet időként háttérbe szorult. A napjainkban erősödő nézet, a tudatos fogyasztói mozgalmak azonban ismét nagyobb jelentőséget tulajdonítanak a döntéshozók egyéni meggyőződésének, melyet különböző, morális elköteleződésük táplál. Az etikai megfontolásokkal gazdagított értelmezési keretek, bár bonyolultabb, mégis valóságosabb értelmezését adhatják a gazdasági folyamatoknak, melyek tanulmányozása így gyakorlati haszonnal is kecsegtet. Tanulmányunkkal a gazdasági etika értelmezéséhez szeretnénk hozzájárulni.

Abstract. According to the common understanding of economic science people following their own preferences looking for ractional decisions which might bring the biggest advantage available. General economic models take this pre-condition as an axiom, however while analysing real processes and motivation, human side, ethics and values cannot be ignored. Business ethics has always been part of economics though having a diminishing role occasionally. Current developing movements of conscious consumers reveal the importance of the topic, highlighting personal creed and moral principles. Analytical frameworks incorporating ethical considerations are albeit more complicated hence offer more realistic interpretation of economic activities and therefore practical benefits at the end. Our study is a general review on this phenomenon.

\section{Bevezetés: A haszonelvűség megjelenése}

Mindennapi értelemben a 'gazdálkodás' kifejezés alatt a magasabb haszon és jólét vezérelte üzleti cselekedeteket, a minél nagyobb profit elérését értjük. Latin megfelelőjét, az 'ökonómiát” a Magyar Nyelv Értelmező Szótára közgazdaságtanként, a javakkal való gondos és takarékos gazdálkodásként definiálja, a vagyon és tulajdontárgyak célszerű elrendezése, elosztása céljából (I1). A kifejezés 
gyökere az 'ökosz' ógörög szó, ami házat, háztartást, családot és családi gazdaságot jelentett (I2). Amint látjuk, egyik eredeti kifejezés tartalmában sincs utalás a többletre való törekvésre, a gyarapodásra - a hangsúly a tulajdonnal való ésszerü, racionális bánásmódon van.

A gazdaság ilyetén való felfogása majd’ 2000 évig volt meghatározó a közgazdaságtanban, ezt követően az „utilitárius fordulat” a haszonelvűség szemléletét helyezte előtérbe. Az elmúlt pár száz évben tehát az ökonómia helyett az ökonomizus vált a gazdasági-társadalmi jelenségek általános keretévé. Erről akkor beszélhetünk „ha a gazdaságosságra, hatékonyságra, versenyképességre való törekvés már nem az emberi haladást szolgálja, hanem öncélként jelenik meg" (TóTH, 2016:30). Az ökonómia vezérfonala az egész közösség számára elérhető jólét hosszú távon való biztosítása a tulajdon beosztó felhasználásával, míg az ökonomizmus a minél szűkebben értelmezett érintettek hasznát szeretné már rövid távon maximalizálni, az áruk korlátlan felhalmozásával (TóTH, 2016).

A morálökonómiai szemlélet körülbelül az 1700-as évek közepéig volt meghatározó a gazdaságban. A közösen vallott erkölcsi szabályok betartása mellett a közjó (common goods) elérése állt a filozófia középpontjában. A fordulatot Adam Smith „A Nemzetek gazdagsága” (1776) című könyvének megjelenésével fémjelzik, amelyben (többek közt) egy önműködő erő működését ismerhetik meg az olvasók, amit egy 'láthatatlan kézhez' hasonlít a szerző. A kéz észrevétlenül is a lehető leghatékonyabb állapotot teremti meg a piacon, amennyiben a gazdaság szereplői saját érdeküket követik a különböző tranzakciók alkalmával. Jóllehet a kifejezés mindössze egyszer szerepel csak a múben, a gazdaságtörténetben mégis vízválasztóként hivatkoznak rá és a jelenségre, aminek népszerűvé válása után egyre inkább a gazdaság haszonelvű értelmezése került előtérbe.

Az utilitarizmus az egyik legjelentősebb erkölcsfilozófiai szemlélet, mely az egyén önérdekkövetését helyezi középpontba. Hipotetikus emberképe a homo oeconomicus, akinek egyetlen célja, hogy döntéshozatala során saját hasznosságát, élvezetét maximalizálja (GLAZER - HIRSCHLEIFER HIRSCHLEIFER, 2009). Smith mellett a filozófia további képviselői John Stuart Mill és Jeremy Bentham voltak, utóbbi még egy pontos „kalkulust” is meghatározott, amely segítségével kiválasztható volt a magasabb hasznot nyújtó cselekvési alternatíva (CSAPÓNÉ, 2008).

A haszonelvű gazdaság alapvető célkitűzése „a lehető legnagyobb boldogság elérése a lehető legtöbb ember számára"1. jóllehet az elmúlt háromszáz évben a közösség érdekeivel való szolidáritás (objektív önérdek) önérdekkövetéssé (szubjektív önérdek) deformálódott (FROMM, 1975 in TÓTH, 2016). A haszonelvűség kritikájaként fogalmazható meg, hogy az egyén áldozattá válhat a „köz” érdekében, amennyiben ezzel teljesül a legnagyobb hasznosság állapota. A többség érdeke ily módon felülírhatja a kisebbség érdekeit, függetlenül, attól, hogy erkölcsileg esetleg a kisebbségnek van igaza.

A haszonelvű ember prototípusával, a homo oeconomicus-sal szemben is megfogalmazhatók ellenvetések. Hiba adottságként tekinteni az önző emberi magatartásra. És bár léteznek tudományágak ahol valóban megdönthetetlen szabályok vezérelnek mindent, az emberi természet mégsem determinisztikus jellegű. A gazdasági életben legfeljebb csak törvényszerüségekről beszélhetünk, a természettudományok törvényei helyett (MUZSLAY, 1995).

\footnotetext{
${ }^{1}$ Az eredeti kifejezés Beccaria, olasz jogtudóstól származik: „La massima felicita divisa nel maggior numero”.
} 
A kritikáktól függetlenül a haszonközpontú látásmód hamar elterjedt s napjainkig az üzleti szféra domináns gazdasági paradigmájaként tartjuk (tartottuk) számon. A hasznosabb - azaz újabb, nagyobb, több és gyorsabb - űzése közben korunk puszta eszközként tekint a természetre és a társadalomra egyaránt. Az alárendelt viszony célja a folyamatos gazdasági fejlődés támogatása (GLIED, 2016). A modell vezérgondolata azonban saját határait is kijelöli: csak addig müködőképes, amíg hajtja a növekedés, utána kifullad (HAJNAL, 2010).

\section{Paradigmaváltás a gazdaságban}

A haszonelvű szemlélet terjedésének ellenére az etikai megfontolások menesztése a gazdaságból korántsem volt minden gazdasági szereplő számára egyértelmű. Mindazonáltal felvetődött a kérdés, hogyan hangolható hát sikeresen össze az erkölcs és az üzlet? A kérdés számos nézőpontból, többféleképpen megválaszolható.

\subsection{Az „erkölcsnélküliség” állapota}

Az amerikai közfelfogás a „Myth of Amoral Business”, azaz „az erkölcs nélküli üzlet” kifejezéssel foglalható össze. Eszerint, mivel az üzleti szféra szereplői általában nincsenek tisztában az etikai elvekkel, ezért munkájuk során nem is követik azokat. Nem szándékosan erkölcstelenek (immoral) ők, inkább az erkölcs nélküliség (amoral) jellemzi tevékenységüket, hiszen meggyőződésük szerint az erkölcsi megfontolásoknak semmi keresnivalójuk nincs az üzleti világban (DE GEORGE, 2014). Az „erkölcs nélküli üzlet” jelenségének magyarázatául az szolgálhat, hogy a vállalkozások alapvető célja nem az, hogy etikai kérdésekben és morális értékekről foglaljanak állást. Sokszor maguk a menedzserek is hiányt szenvednek az ilyen jellegű tanulmányokban. Az angol nyelvű klisé szerint „az üzlet lényege maga az üzlet”2. Az üzleti életben tehát nincs helye a jótékonyságnak, a szociális jólét kérdéseinek, és így az erkölcsöknek sem. (DE GEORGE, 2014).

Az „ügynök-megbízó” dilemma (TóTH, 2016) elterjedése előtti időkben a vállalkozások zöme családias környezetben, kisléptékű szervezetként működött. A nagy cégek, óriás társaságok megjelenésével aztán egyre elterjedtebb lett a 'kinevezett' vezetők (manager) alkalmazása, aki a tulajdonosok (stockholder, shareholder) kívánalmainak megfelelően irányítja a céget. Az ügynök és a megbízó szerep kettéválásával párhuzamosan egyre több, az üzleti életet szabályozó jogszabály látott napvilágot. A menedzserek már nem vetíthették ki, kérhették számon saját erkölcsi meggyőződésüket az alkalmazottaiktól, hanem semleges hozzáállást kellett tanúsítaniuk az üzlethez. A cél a jogszabályi környezetnek és a társadalmi (tulajdonosi) elvárásoknak való megfelelés lett, az erkölcsöt pedig egyre inkább a személyes tér részeként értelmezték, ami így akár egyénenként eltérő is lehetett. Mivel a törvények és szabályok betartása szükséges és - látszólag - elégséges feltételt teremtett a sikeres üzleti tevékenységekhez, így a morális elvárások ignorálása, és az „erkölcs nélküli üzlet” szemlélete logikus választásnak tűnt.

A morálökonómiai nézőpont gyengülése a korábban egységes gazdasági-társadalmi közfelfogás szétesését eredményezte. A jelenségről Baranyi így ír: „Az európai politikai gondolkodásmód és

${ }^{2}$ Angolul: „The business of business is business". 
közmorál - nagyrészt a magát „felvilágosodásnak” nevező eszmeáramlat eredményekéntmegfosztotta magát az alapvető bizonyosságok forrásától: a bibliai keresztény alapoktól. A nyugati civilizáció országaiban ugyan továbbra is elismerik az etikai normákat és hangoztatják fontosságukat, azonban e normák eredeti közegükből kiragadva talajvesztetté, ésszerúen alá nem támaszthatókká váltak" (BARANYI, 2017:334). Ez a jelenség számos napjainkban tetten érhető probléma forrása.

A globalizációs folyamatok intenzívvé válásával tovább változott a helyzet. A mai gazdasági szereplő azzal szembesül, hogy a természeti erőforrásaink végesek, és az ökoszisztéma érzékeny rendszerében cselekedete akkor is jelentősen hat másokra, ha ez szándékolatlan. Ebben a (gazdasági) környezetben egyre világosabb, hogy (üzleti) döntéseink minden esetben értékítéletet is hordoznak magukban. A megváltozott üzleti szemlélet (mandate of business) pedig azt hirdeti, hogy egy vállalkozás értékét a pénzügyi indikátorai mellett immár erkölcsi 'teljesítménye' is befolyásolja (DE GEORGE, 2014).

\subsection{Etikai megfontolások a gazdaságban}

A 21. században tehát egy új dilemmával állunk szemben: a társadalmi értékek és etikai kérdések mérlegelése már szerves részét képezik mindenféle döntéshozatalnak, ami lassan az „erkölcs nélküli” éra térvesztéséhez vezet. Az üzlet esszenciáját mindig az adott hely és kor, és annak társadalma által közösen vallott nézőpont, értékek határozzák meg. Mást jelentett a 70-es évekbeli Szovjetunióban, mást a 90-es évek paternalista Japánjában és mást jelent ma Magyarországon is. Voltaképpen tehát az üzleti felfogás lényegét mégis csak egy társadalmilag elfogadott és követett erkölcsi keret adja (DE GEORGE, 2014).

Az üzleti szféra a társadalom integráns részét képezi. Az erkölcsök az emberi viselkedés szabályaiként értelmezhetők, amelyek megmondják, mi helyes és mi helytelen. Ily módon az üzletelés (mint emberek közötti viszony) szintén erkölcsi alapokon nyugszik. Az üzleti tevékenység, a többi társas tevékenységhez hasonlóan, megköveteli a közös szabályok ismeretét és betartását - e nélkül nem is működhetne a dolog.

Az üzleti célú emberi cselekedetek tehát szintén az erkölcsi szabályok hatálya alá tartoznak - mivel azonban ez túlságosan is egyértelmű, néha hajlamosak vagyunk erről megfeledkezni. Az üzlet és az erkölcs különállása tehát nehezen védhető álláspont. Az üzleti etika célja pedig nem feltétlenül az erkölcs megváltoztatása, hanem az erkölcs figyelembevétele az üzleti döntéshozatalban (DE GEORGE, 2014).

Az üzleti etika jelentése nem más, mint az emberek által vallott és követett morális normák alkalmazása az üzleti életben (TÖRÖK, 2002). Nem beszélhetünk tehát egy különálló 'normacsomagról', amely csak az üzleti életben alkalmazandó - itt ugyanúgy kerülendők a mindennapi vétkek, mint a csalás, lopás, hazugság, mások bántalmazása vagy jogaik megsértése. A Tízparancsolat sem köti meg, hogy a különböző bűnöket az élet mely területén kell kerülni - egyszerűen csak megtiltja azokat. Az „úgy bánj másokkal, ahogy szeretnéd, hogy mások bánjanak veled!” életfilozófia szintén iránymutatást ad az üzleti élet útvesztőiben is.

Az üzleti etikai normák egyidősek magával az üzletkötéssel. Már az ókori bölcsek közül Platón és Arisztotelész is sokat foglalkozott a közjó fogalmával, valamint a tisztességes kereskedelem 
fontosságával. A középkorban aztán az igazságos ár és a kamat kérdése került a viták középpontjába (Aquinói Szent Tamás és mások), majd a református tanítók (Luther, Kálvin) alapozták meg a protestáns munkaetikát (Max Weber), amely jelentős hatással volt az üzletkötés moráljára. A keresztény egyház társadalmi tanításai ${ }^{3}$ révén, az 1891-ben XIII. Leo által elsőként kiadott pápai enciklika, a 'Rerum novarum' óta, rendszeresen tárgyalja a társadalmi igazságosság (méltányos bérek, munkához való jog, az emberi munka elsőbbsége a tőkejavakkal szemben, stb.) kérdéseit ${ }^{4}$ (TóTH, 2016). A közgazdaságtan atyjának nevezett Adam Smith is, a számára halhatatlanságot hozó értekezése ${ }^{5}$ előtt „Az erkölcsi érzelmek elmélete” 6 című művében a morális meggyőződés fontosságáról írt. Smith kortársa, az olasz Antonio Genovesi (2016 [1765]) és gondolkodótársai szintén a „polgári közgazdaságtan” elveit hangsúlyozták. A modernkori filozófusok közül aztán John Stuart Mill, Kant, Hegel és Marx is foglalkoztak a gazdasági igazságosság és az erkölcsök kérdéseivel.

Az 1970-es években az üzleti etika társadalmi je lensége (ismét) egyre elterjedtebb lett és a 80-as években már politikai mozgalmaként beszélhetünk róla (HILTON, 2003). Ennek eredményeként megjelentek a vállalati etikai kódexek (GULYÁS E., 2011), a cégen belüli etikai programok, a terület intézményi felelősei. Az akadémiai szektorban tankönyvek, jegyzetek íródtak, ezzel foglalkozó szakmai társaságokat és folyóiratokat hívtak életre, a főiskolák, egyetemek pedig kurzusokon keresztül kezdték megismertetni a témát az érdeklődőkkel.

\subsection{A méltányosság-elmélet és a felelős gazdasági döntéshozatal modellje}

A klasszikus közgazdaságtani nézőpont szerint a gazdasági szereplők döntéshozataluk során racionálisan viselkednek. A racionalitásnak Samuelson szerint két feltétele van: a döntéshozó a választáshoz szükséges információk teljes körének birtokában van (1), így minden ismerete adott ahhoz, hogy olyan (jó) döntést hozzon, amellyel hasznát maximalizálni tudja (2). Az önérdekkövetés mindent felülíró szabályszerűségét hirdető és ezzel egyidejűleg a mások érdekeinek figyelembevételét tagadó szemléletnek a közgazdaságtanban nagyon egyszerű oka van. A valóság leegyszerűsítésével lehetőség kínálkozik a gazdasági helyzeteket magyarázó általános folyamatok megfogalmazására, modellek felállítására.

A valóságban azonban a tiszta önérdekkövetés korántsem az egyetlen lehetséges magatartás. Az emberek gyakran „rendbontóan” (THALER, 2016) viselkednek, amitől a felállított modellek bizony téves eredményeket hoznak. Számos közgazdász (Smith, Becker, Arrow, Samuelson; Sen, stb.) írt már arról, hogy az ember képes tágítani szűk látókörén és a saját hasznán túl mások érdekeit is figyelembe venni egy-egy döntési helyzetben. Adam Smith szerint „az ember természete minden látszólagos önzése ellenére jó adag önzetlenséget mutat, s ez alól még a társadalmi rend elleni legvadabb lázadók sem kivételek" (TÓTH, 2016:92). Egyes kutatások azt is igazolták, hogy bizonyos esetekben az ember kifejezetten a saját önérdeke ellenében is dönthet (ROTH et al; 1991; FEHR-GÄCHTER, 2000). Az önérdekkövetés tehát nem ad magyarázatot minden piaci jelenségre, így érdemes további viselkedési

\footnotetext{
3 Angolul: Catholic Social Teaching vagy Thought (CST)

${ }^{4}$ Lásd a Metszetek c. folyóiratban megjelent összefoglaló cikkünket a keresztény nézőpontú menedzsmentről „AZ ÜZLETI KAPCSOLATOK ERKÖLCSI ÚJJÁÉPÍTÉSE' címmel (Tóth-Csapó, 2017).

${ }^{5}$ A Nemzetek gazdagsága, 1776

${ }^{6}$ Angolul: The Theory of Moral Sentiments (1759)
} 
módokat is megvizsgálni, úgy, mint az altruizmus, a reciprocitás, a méltányosság vagy a felelősség eseteit.

$\mathrm{Az}$ altruizmus az önérdekkövetés ellentéteként értelmezhető, olyan látásmód, amikor döntéshozatalunkban mások jóléte is szerephez jut, sőt, erősen befolyásol minket (BECKER, 1976). Az altruista ember hasznosságérzete minden esetben függ a döntésével másnak okozott hasznosság fokától. Az altruizmus lényege a feltétel nélküliség, azaz egy altruista a másik jólétét az általa hozott döntéstől függetlenül figyelembe veszi. Az altruista ember hasznossági függvénye így a következőképp adható meg:

$$
\mathrm{U}_{\mathrm{i}}=\mathrm{f}\left(\pi_{\mathrm{i}}, \mathrm{U}_{\mathrm{j}}\right)
$$

ahol $U_{\mathrm{i}}$ az (altruista) i-dik ember hasznossága, $\pi_{\mathrm{i}}$ az i-dik ember kifizetése, „jövedelme”, $U_{\mathrm{j}}$ pedig a j-dik ember által észlelt hasznosság (GULYÁS A., 2007). Látható, hogy az altruista hasznossága tekintetében alapvető befolyásoló tényező a másik fél által észlelt hasznosságérzet (BECKER, 1976). Az altruizmus kritikájaként Miller (2001) megjegyzi, hogy az ilyen viselkedés hátterében is rendszerint önérdek húzódik. Az altruista ember morális érvek mögé rejtve ugyan, de hasonlóan saját hasznát (egészségesebb táplálkozás, luxus termék, ízletesebb élelmiszer) követi etikus vásárlásai során.

A reciprocitás, más néven a „szemet szemért elv”, ismétlődő szituációkban kristályosodik ki, amikor is döntésünk során tükrözzük a másik ember felénk való hozzáállását (GULYÁS A., 2007).

A méltányosság a két hozzáállás között félúton helyezkedik el. Egy méltányos döntéshozatal során saját önérdekkövetésünk mellett bár figyelembe vesszük a döntésünk másokra gyakorolt hatását, ugyanakkor a végső döntés mindig függ az adott helyzettől, a döntéshozó által vélt erkölcsi normáktól és a másik emberhez fűződő viszonyától (GULYÁS A, 2007; 2011). A méltányosság-elméletekben az egyén nem a másik hasznosságát veszi döntése alapjául, hanem a másik ember jólétének valamely elemét, például a számára realizálódó kifizetés mértékét. Ebben az esetben tehát a méltányos döntést hozó egyén számára az lesz kardinális, hogy a másik is megkapja azt az összeget, ami neki jár.

Ez alapján a méltányos döntéshozatal modellje az alábbi logikát követi:

$$
U_{i}=f\left(\pi_{i}, \pi_{j}\right)
$$

ahol i a méltányos döntést hozó egyén, míg j a másik fél. A két modell közötti eltérést legjobban az a helyzet szemléltetni, amikor a 'j' egyén altruista. Ebben az esetben, ha 'i' méltányosságból lemond saját kifizetése egy részéről 'j' részvevő számára (bár ezáltal a saját hasznossága változatlan marad), gyakorlatilag előfordulhat, hogy ezzel 'j' hasznosságát akaratán kívül is csökkentette (GULYÁS A., 2007)!

Az etikus elveket mentén elkötelezett közgazdászok már évek óta vallják, szükség van az erkölcs közgazdaságtanba való (re)integrálásának. Schumacher, Sen és Fromm (többek közt) munkáikban ebből az ötletből indulnak ki, és sürgetik a gazdasági paradigmaváltást (GLIED, 2016). Ennek egyik formája a másikért érzett felelősség esete.

A felelősség kérdéskörének elemzése Hans Jonas német-amerikai filozófus nevéhez füződik, aki morálfilozófiai szemszögből közelítette a témát a 1980-as években. Meglátása szerint a felelősség egy alá-fölérendelt, aszimmetrikus viszonyt eredményez a cselekvő és a cselekvésben érintett között, 
amelyben a cselekvő előzetesen (ex ante) felméri cselekedetének következményét, hatását. Kétféle úton kerülhetünk felelősségi viszonyba: természetesen, amikor az érintettek az akaratuktól függetlenül kerülnek függőségi viszonyba, ahogy például a szülő felelős lesz gyermekéért, illetve szerződéses úton, mint például a politikusok esetében, akik tervezett, szándékolt cselekvés következtében felelnek másokért. A gazdasági döntéshozók a két pólus között állnak: szerződéses kapcsolataik miatt „hivatalból” felelnek az alkalmazottaikért, fogyasztóikért, beszállítóikért, ugyanakkor egy széles társadalmi rétegre természetes úton vannak hatással (pl.: helyi közösségek, természet), még ha ezzel nincsenek is feltétlenül tisztában (JONAS, 1984 in ZSOLNAI, 1998;).

A gazdasági szereplőknek tehát akaratuktól függetlenül is több tényezővel kell számolniuk döntéshozataluk során. A felelős gazdasági döntéshozatal túlmutat az önérdekkövetésen, és a racionalitás adta szervezeti célok követése mellett megjelenik a respektus tényezője is (GOODPASTER, 1983). ${ }^{7}$ Ez a másik tényező azt feltételezi, hogy a cselekvő átgondolja és figyelembe is veszi döntéseinek másokra gyakorolt hatását a döntéshozatal során. Ez gyakorlatilag nem más, mint a korábban tárgyalt méltányosság maga. „A respektus tehát többet jelent annál, hogy másokban csupán saját céljaink megvalósításához szolgáló eszközöket lássunk. A más életek iránt érzett respektus azt jelenti, hogy az egyén mások szükségleteit és érdekeit is komolyan veszi, nem erőforrásként, hanem korlátozó tényezőként veszi azokat számba döntései meghozatalakor" (GOODPASTER-MATTHEWS, 1982 in ZSOLNAI, 1998:155).

Bár mindkét tényező egyidejű megléte szükséges a felelős döntéshozatalhoz, a racionalitás logikailag mégis megelőzi a respektust, hiszen az elérhető alternatívák közötti választáshoz szükségünk van a különböző kimenetekről való információkra. Ha úgy döntünk, hogy figyelünk másokra is, akkor a tényszerűség mellett a respektus elveire is támaszkodunk a választáskor. Mi történik azonban akkor, ha a következmények nem egyértelműek vagy nem lehet azokat könnyen előrelátni, megbecsülni?

A respektus - következményelvüsége miatt - nem feltétlenül nyújt elégséges támpontot a döntéshez. Ilyen esetekben segítenek az etikai normák, amelyek mindig „kéznél vannak” és morális alapot adnak döntéseinkhez. A normákat figyelembe vevő döntéshozatalt deontikus szemléletnek nevezzük, lényege, hogy a következmények mellett vagy helyett, az egyén a számára fontos etikai elveknek akar megfelelni. A kérdés megválaszolásához tehát Zsolnai bevezeti a felelős döntéshozatal modelljének harmadik tényezőjét, a deontikus változót. A felelősen gondolkodó ember így döntéshozatalában olyan alternatívát választ, amely követi erkölcsi meggyőződését (normák), leginkább szolgálja a saját vagy szervezete céljait (racionalitás), ugyanakkor figyelembe veszi az érintettek érdekeit is (respektus) (ZSOLNAI, 1998). ${ }^{8}$ A racionális döntéshozatal ezzel szemben a felelős döntéshozatalnak csupán egy

\footnotetext{
${ }^{7}$ Goodpaster modelljében a racionalitás nem fedi a közgazdászok által használt racionalitás fogalmat. Míg a közgazdaságtudományban racionálisan az viselkedik, aki a döntéshozatalhoz szükséges teljes információ birtokában hasznosságát maximalizálva dönt valamiről, itt a racionalitás azt jelenti, hogy az érzelmek mellőzésével (1), a választási alternatívák és azok következményeinek alapos felmérése után (2), egyértelműen definiált célokért (3) tudatosan, figyelmesen cselekszik valaki (4).

${ }^{8}$ A felelős választást eredményező döntés leírása ebben az esetben a következő:

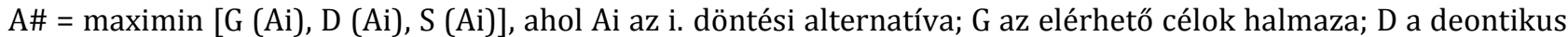
változó, a normák értéke; S pedig az érintettek (stakeholderek) érdekei (ZSOLNAI, 1998:158). A maximin szabály értelmében a felelősen cselekvő azt az alternatívát fogja választani, amely legrosszabb esetben is a legnagyobb 
leegyszerűsített, redukált verziója, ${ }^{9}$ amelyben egyedüli cél az elérhető hasznok (adott esetben profit) maximalizálása. Ebben a döntéshozatali környezetben „nincsenek” befolyásoló normák, sem zavaró tényezőként értelmezhető érintettek.

\subsection{A tudatos, a felelős és az etikus fogyasztó értelmezése}

$\mathrm{Az}$ elméleti modellek mellett a gyakorlatban is egyre több példát láthatunk az etikus üzleti folyamatokra, az ember-, illetve természetközpontú fogyasztói és vállalati gondolkodás ma már szerencsére nem ritka jelenség. A tudatos, etikus, méltányos, felelős vásárlás olyan kifejezések, amelyekkel mind gyakrabban találkozhatunk a szakirodalomban is, így érdemes róluk néhány szót váltani.

A tudatos fogyasztó döntését racionális elvek mentén, lelkiismeretesen igyekszik meghozni. A vásárlási szokásait választott megfontolása alapján kész megváltoztatni, jobb esetben visszafogni, csökkenteni is fogyasztását. (SCHOR - WILLIS, 2009, GULYÁS E. 2008a). A hagyományos fogyasztóvédelem értelmezésében tudatos fogyasztó az, aki nyitott szemmel jár a boltokban, keresi és igényli is az termékinformációkat, tisztában van fogyasztói jogaival, és ha kell, kész élni is velük (TVE, 2018).

DUDÁS (2011) tanulmányában két nagy halmazra bontja a tudatosan fogyasztókat. Az elsőbe rendezi az önérdek követőket, akik vásárlásuk során valamely előre felállított elvek mentén saját maguknak akarnak kedvezni. A döntési prioritásuk alapján e fogyasztók lehetnek például ár-, érték-, márka-, minőség-, egészség- vagy táplálkozástudatosak. A másik csoportba azon emberek tartoznak, akik vásárlásaik során önös érdekeik mellett vagy helyett további tényezőket is figyelembe vesznek. Ők a felelös fogyasztók, akik döntésének középpontjában szintén különböző megfontolások (állat-, növény-, környezetvédelem stb.) állhatnak.

A 'törődő' fogyasztó jelensége tehát általában a fogyasztói jogok ismeretében, szükség szerint azok alkalmazásában, a termékekről való módszeres információgyűjtésben és értelmezésében ölt testet. Ilyen ember az, aki vásárlása alkalmával saját vagy mások érdekeit előzetesen felállított koncepciója mentén követi (DUDÁS, 2011). Ez TÖRŐCSIK (2003:69) szerint kiegészül azzal, hogy „a felvilágosult fogyasztó bizalmatlan, szkeptikus, nem mer hinni sem a gyártónak, sem a kereskedőnek".

A tudatosság abban is megjelenik, hogy ez a típus minden egyes vásárlása alkalmával egyben arról is döntést hoz, hogy pénzét mire költi, milyen értékeket valló vállalkozásoknak szánja és azzal az adott vállalkozás mihez kezd, azt mibe fektetni be. Vásárlásunk „szavazat” - akár akarjuk, akár nem (GULYÁS, 2007). Az ezt vallók célja nem az, hogy a többi kevésbé megfontolt, vagy informált embert bűnösnek állítsa be, hanem egy olyan szemléletformálás segítése, amelyben világossá válik, hogy a döntéseinkkel valóban társadalmi változást tudunk okozni a rendelkezésünkre álló, pénzeszközeinkben tárgyiasuló fogyasztói erő (consumer power) által. Fenti koncepció a

eredményhez vezet a többihez képest, azaz azt a lehetőséget, amely az elérhető kimentek közül a legkevésbé rossz megoldást nyújtja.

${ }^{9}$ A racionális döntéshozatal függvénye: max G(Ai) (ZSOLNAI, 1998). 
fogyasztópolgárság (consumer citizenship) fogalmára épül, amin belül a fogyasztás mint a közügyekben való részvételi forma kap értelmet (GULYÁS E., 2007; GULYÁS E., 2008b, WHELEER, 2011).

A vásárlási tevékenység ma már egyfajta kommunikációs folyamatnak tekinthető (DOUGLASISHERWOOD, 1996), amely során a fogyasztó meggyőződéséről, hiedelmeiről, az általa vallott és követett értékekről, világlátásáról informálja a piaci szereplőket. Amennyiben a vásárlás valamilyen tudatos, etikus meggyőződés mentén valósul meg, ez még inkább eszköze lehet, hogy egyéni és társadalmi identitásunkat kifejezésre juttassuk (HILTON, 2003).

Ezzel összhangban van Törőcsik véleménye, aki szerint a termelő-kereskedő-fogyasztó hármasában a jövőben egyre inkább a fogyasztóé lesz a főszerep. A fogyasztói hatalom megszilárdulásához azonban a gyakran még széttöredezett vásárlói csoportok további koncentrációja szükségeltetik, amit ugyanakkor támogatnak a jelenlegi globális piaci trendek és az Internet „társkereső funkciói” (TÖRŐCSIK, 2007).

Felelős magatartásunkat kétféleképpen élhetjük meg: vagy szándékosan elzárkózunk a vásárlástól (nemfogyasztás), esetleg bojkottáljuk adott termék illetőleg egy vállalkozás áruinak fogyasztását (ez a negatív formája) vagy kifejezetten ragaszkodunk egy bizonyos termékhez és vásárlásunkkal támogatjuk, azáltal díjazzuk a termelőt ${ }^{10}$, gyártót (ez a pozitív út). Ez utóbbira példa lehet az ökológiai címkével ellátott termékek, vagy a méltányos kereskedelemből származó áruk vásárlása, míg a negatívra valamilyen etikátlan cég elutasítása (CHERRIER, 2007; NEWHOLM-SHAW, 2007).

A felelős fogyasztáson belüli fogyasztói kategóriák lehatárolása már korántsem egységes. DUDÁS (2011) tipizálása nyomán megkülönböztethetünk társadalmilag felelős (1) és környezettudatos (2) fogyasztást, valamint etikus (3) vásárlói magatartást.

A társadalmilag felelős ember (socially responsible consumer) egyéni igényeinek kielégítése során vásárlása közösségre gyakorolt nyilvános hatását is figyelembe veszi, valamint igyekszik, vásárlási erejével társadalmi változásokat előidézni (WEBSTER, 1975).

A környezettudatos szemléletnek három területét is beazonosíthatjuk. (1) Megélhetem ezt az elköteleződésemet vásárlásaim alkalmával (kifejezetten kereshetem a környezetvédő termékeket, műanyag zacskók elutasítása, visszaváltható termékek előnyben részesítése); (2) igyekezhetek a napi életvezetésemben is a kevésbé környezetterhelő megoldásokat alkalmazni (kerékpáros vagy tömegközlekedés, szelektív hulladékgyűjtés, stb.); illetve (3) különböző szemléletformáló és tevőleges akciók során még aktívabban támogathatom az ügyet (DUDÁS, 2006). ELKINGTON és HAILES (1988) „The Green Consumer Guide” című könyve nagyban hozzájárult e szemlélet elterjedéséhez.

Az etikus fogyasztó a rendelkezésre álló információk alapján racionálisan mérlegeli az elérhető (általános) kereskedelmi és egyéb alternatív megoldásokat, amelyek alapján igyekszik a számára és környezete számára leginkább megfelelő döntési alternatívát kiválasztani (ADAMS - RAISBOROUGH, 2010). Az etikus fogyasztás abban különbözhet a társadalmilag felelőstől, hogy mélyebb fókusszal bír. Nem általában a társadalmi érdekekre koncentrál, hanem egy, a vásárló által kiválasztott, kedvezményezett csoport érdekeit helyezi előtérbe (DUDÁS, 2011). TALLONTIRE et al, (2001) és

${ }^{10} \mathrm{~A}$ bojkott (boycott) kifejezésre rímelve, a támogató etikus vásárlást ( to buy) az angol szakzsargon 'buycott'-nak nevezi. Részletesebben lásd Friedman témáról írt 1996-os és 1999-es cikkeit. 
HILTON (2003) az etikus fogyasztás részeként különít el három fókuszterületet, amelyek az állatok jóléte (1), a környezetvédelem (2), és az emberi jogok, munkakörülmények és a méltányos kereskedelem területe (3). SZMIGIN és társai (2009) pedig szinonimaként használják az etikus és a tudatos jelzőket.

A tudatos és felelős fogyasztók értelmezései között, látjuk, nagyfokú átfedéseket tapasztalhatunk. A környezettudatosságba beletartozik a természeti környezet mellett az állatvilág védelme is, a társadalmi felelősségnek része az embertársaimmal szemben való etikus viselkedés is. A LOHAS (Lifestyle of Health and Sustainablity) hívei egyaránt fontosnak vélik a fenntartható (társadalmi) fejlődést és az (ön)egészségtudatosságot (SZAKÁLY et al, 2015), a méltányos kereskedelem (fair trade) elvei közül pedig ugyanolyan hangsúlyt kapnak a társadalmi, gazdasági és ökológiai szempontok. A definíciók megfogalmazása és a fogyasztói csoportok lehatárolása ily módon a kutató érdeklődésének és témájának megfelelően változhat.

Adottság, hogy a különböző fogalmi lehatárolások meglehetősen rugalmasak. Meglátásom szerint ez nem feltétlenül baj, hiszen nem egzakt definíciók megadása a célunk, hanem a jelenség főbb jellemzőinek feltárása, megértése. A kulcsszavak a társadalmi felelősség, a tudatos vásárlási döntés, és a humán és természeti környezetünk óvása. Alacsonyra tehető azon fogyasztók száma, akik minden esetben a fenti definícióknak megfelelően döntenek. Úgy gondolom, hogy a lényeg nem is a kizárólagosságban rejlik, hanem, hogy a vásárlási szokásainkba beépüljön ez a szemléletmód.

$\mathrm{Az}$ ilyen megfontolt magatartás tehát nem azt jelenti, hogy minden esetben jól döntök, hanem hogy olyan ember vagyok, akit érdekel, hogy jó döntéseket hozzon a különböző helyzetekben. (CSAPÓNÉ ÁRVÁNÉ idézi NUPROTEST, 2011).

\section{Következtetések}

Összegzésül elmondhatjuk, hogy az etikus/felelős fogyasztói magatartás komplex társadalmi jelenség, ami egyre elterjedtebb a világon. Növekszik azon szervezetek száma, amelyek fókuszában a környezeti fenntarthatóság, a társadalmi igazságosság, valamint a természettel, a társadalommal és a jövő generációival szembeni méltányos viselkedés áll. A globalizációellenes platformok, vagy alternatív megoldásokon gondolkodó szakmai csoportok tevékenységei számos területet fednek le a globális ökológiai veszélyektől kezdve, a méltányos kereskedelem kezdeményezésén és a szegénység problémáján keresztül, a fenntartható fejlődésig (BODA-GULYÁS E, 2006). Számos tanulmányt olvashatunk a téma iránti érdeklődés magyarországi térnyeréséről is (GfK, 2014, 2016, 2017a, 2017b; TVE, 2017).

A gazdaságetikai kérdések mögött még mindig a vállalatok és a társadalom érdekei között húzódó érdekellentét áll. Habár egyre világosabban látszik, hogy az üzleti szféra szereplői felismerni vélik a fogyasztó mint számukra legfontosabb piaci szereplő (kulcs)fontosságát, aki elégedettségén jövőbeli túlélésük és sikerük áll vagy bukik. A jelenség tovagyűrűző hatásaként pedig megemlíthetjük a fogyasztóvédelmi szervezetekre gyakorolt nyomást és szemléletformálást, amely következtében a korábban felsorolt témák egyre több hagyományosnak tekinthető fogyasztói szervezetet foglalkoztatnak. Eredményül azt kapjuk, hogy az „eddig elsősorban gazdasági térként értelmezett 
modern piac morális cselekvési térré, a társadalmi részvét és szabályozás eszközévé" válik (GULYÁS E, 2008a:106). A viselkedés-közgazdaságtan térnyerése is ez irányba mutat, a gazdaság emberi oldalát hivatott hangsúlyozni, ahol ökonok (THALER, 2016) helyett való emberi lények hoznak üzleti döntéseket, saját meggyőződésük, világnézetük szerint. A pusztán matematikai függvények alkalmazása helyett a valósághoz közelebbi eredményekre juthatunk, ha kutatásaink során a jövőben nagyobb figyelmet szentelünk a gazdasági döntéshozatal főszereplőjének, az embernek.

\section{Hivatkozások}

[1] ADAMS M. - RAISBOROUGH J., 2010: Making a difference: ethical consumption and the everyday. The British Journal of Sociology. Volume 61, Issue 2, p. 256-274.

[2] BARANYI, 2017:334: Baranyi Árpád. (2017): Keresztény társadalometika In BARITZ, S. L. DABÓCZI G. (szerk.) Emberközpontú gazdaság, KETEG Alapítvány

[3] BECKER G., 1976: Altriusm, Egoism and Genetic Fitness: Economics and Sociobiology, Journal of Economic Literature, Vol 14. No 3.

[4] BODA Zs. - GULYÁS E, 2006:, The Ethical Consumerism Movement in Interdisciplinary- Yearbook of Buiness Ethics, 2006, pp 141-154

[5] CHERRIER H., 2007: Ethical consumption practices: Co-production of shelf-expression and social recognition. Journal of Consumer Behaviour. 6. 5.

[6] CSAPÓNÉ R. T., 2008: Üzleti etika. Főiskolai jegyzet. Budapesti Gazdasági Főiskola KVIFK

[7] CSAPÓNÉ - ÁRVÁNÉ idézi NUPROTEST blog, 2011: Csapóné Riskó Tünde - Árváné Ványi Georgina, Results of a survey on conscious consumerism and food comsumption habits among Hungarian higher education students in Agricultural Informatics 2011 Conference Proceedings Innovative Information Technologies in Agriculture, (edited by Herdon Miklós, Rózsa Tünde, Szilágyi Róbert) pp 86-94., Debrecen, 2011.

[8] DE GEORGE R. T., 2014: Business Ethics, Pearson Education Limited, 2014

[9] DOUGLAS M. -ISHERWOOD B., 1996: The World of Goods - Towards an Antropology of Consumption. London, Routledge.

[10] DUDÁS K., 2006: A környezettudatos vásárlói magatartás elemzése, Marketing és Menedzsment, 2006/ 5-6.

[11] DUDÁS K., 2011: A tudatos fogyasztói magatartás dimenziói, Vezetéstudomány, XLII. évf. 2011. 7 8 szám.

[12] ELKINGTON J. - HAILES J., 1988: The Green Consumer Guide. London: Gollancz.

[13] FEHR E. -GÄCHTER S. , 2000: Fairness and Retaliation: The Economics of Reciprocity. Journal of Economic Perspectives, Vol 14., No 3.

[14] FROMM E., 1975: In Tóth Gergely, Gazdasággép, L'Harmattan - KÖVET Egyesület, 2016, p60.

[15] GENOVESI A. , 2016 [1765]: Értekezések a kereskedelemrôl avagy a polgári gazdaságról, Kairosz Kiadó, Budapest, 2016

[16] GfK, 2014: Növekszik a valódi gyümölcs- és herbateák népszerüsége, https://www.mediainfo.hu/hirek/article.php?id=30969 letöltve: 2014.03.10. 
[17] GfK, 2016: Növekszik az egészségesnek tartott élelmiszerkategóriák fogyasztása, 2016. március 02. https://www.gfk.com/fileadmin/user upload/country one pager/HU/documents/20160302 G fK Egeszsegtudatossag az etkezesben.pdf letöltve: 2016. november 17.

[18] GfK, 2017a; Növekszik a vitaminvásárlók aránya, 2017. 04.24. http://www.gfk.com/hu/insightok/infographic/novekszik-a-vitaminvasarlok-aranya/ letöltve: 2018. február 21.

[19] [19] GfK, 2017b; A GfK a jövő pénzügyi fogyasztóját kutatja, 2017.05.30.

http://www.gfk.com/hu/insightok/press-release/a-gfk-a-jovo-penzugyi-fogyasztojat-kutatja/ letöltve: 2018. február 21.

[20] GLAZER A. - HIRSCHLEIFER J. - HIRSCHLEIFER D., 2009: Mikroökonómia - Árelmélet és alkalmazásai - Döntések, piacok és információ, OSIRIS KIADÓ KFT.

[21] GLIED V., 2016: A halványtól a mélyzöldig, Publikon Kiadó

[22] GOODPASTER K. E., 1983: The Concept of Corporate Conscience, Journal of Business Ethics, No 1.

[23] GOODPASTER K. E. - MATTHEWS J. B., 1982: Can a Corporation have a Conscience? Harvard Business Review, in ZSOLNAI, 1998: ZSOLNAI L., 1998: A felelős gazdasági döntéshozatal modellje, Közgazdasági Szemle, XLV. évf., 1998. február, pp 154-162.

[24] GULYÁS A, 2007: A méltányosságelmélet alapjai, Közgazdasági Szemle, LIV. évf., 2007. február, pp 167-183

[25] GULYÁS A, 2011: Diktátor a barátom? A barátság és a méltányosság kapcsolata, Közgazdasági Szemle, LVIII. évf., 2011. május, pp 430-444

[26] GULYÁS E 2007: Az etikus fogyasztás mint a közügyekben való részvétel, Politikatudományi Szemle XVI/4. pp 112-126.

[27] GULYÁS E, 2008a: Az etikus fogyasztás értelmezései, Szociológiai Szemle 2008/1, pp 106-127.

[28] GULYÁS E 2008b: Fogyasztópolgár: Hatékony politikai jelszó vagy beágyazott társadalmi jelenség?, Politikatudományi Szemle XVII/4. pp 175-182.

[29] GULYÁS E , 2011: Sustainability issues in the ethical codes of hypermarkets, Society and Economy 33 (2011) 1, pp 111-129

[30] HAJNAL K., 2010: Itt és most. Helyi megoldások a globális válságra. Zöld Völgyért Egyesület, Bükkösd,

[31] HILTON M., 2003: Consumerism in Twentieth-Century Britain. Cambridge University Press, Cambridge

[32] JONAS H., 1984: The Imperative of Responsibility. University of Chicago Press, Chicago in ZSOLNAI L., 1998: A felelős gazdasági döntéshozatal modellje, Közgazdasági Szemle, XLV. évf., 1998. február, pp 154-162.

[33] MILLER D., 2001: The dialectics of shopping, Chicago. The University of Chicago Press

[34] MUZSLAY I., 1995: Gazdaság és erkölcs, Márton Áron Kiadó, Budapest

[35] NEWHOLM T. -SHAW D., 2007: Studying the ethical consumer: A review of research October 2007Journal of Consumer Behaviour 6(5):253-270

[36] ROTH A. E. - PRASNIKAR V. - OKUNO-FUJIWARA M. - ZAMIR S., 1991: Bargaining and Market Behavior in Jerusalem, Ljubljana, Pittsburgh and Tokyo: An Experimental Study. American Economic Review, Vol 81. 5. 
[37] SCHOR J. B. - WILLIS M., 2009: Conscious Consumption. Results for a survey of New Dream members. https://newdream.org/consumption/survey.pdf

[38] SZAKÁLY Z. - PETŐ K. - POPP J. - JASÁK H., 2015: A fenntartható fogyasztás iránt elkötelezett fogyasztói csoport, a LOHAS szegmens jellemzôi. Táplálkozásmarketing, 2015.2 (1)

[39] SZMIGIN I. - CARRIGAN M. - McEACHERN M. G., 2009: The Conscious Consumer: taking a flexible approach to ethical behaviour. International Journal of Consumer Studies. 3.2.

[40] TALLONTIRE A. - RENTSENDORJ, E., BLOWFIELD, M., 2001: Ethical Consumers and Ethical Trade - a Review of Current Literature. http://www.nri.org/publications/policyseries/PolicySeriesNo12.pdf

[41] THALER R. H., 2016: Rendbontók, A viselkedési közgazdaságtan térnyerése, HVG Kiadó

[42] TÓTH G., 2016: Gazdasággép, L’Harmattan - KÖVET Egyesület, 2016

[43] TÖRÖK A., 2002: Üzleti etika, Századvág Kiadó

[44] TÖRŐCSIK M, 2003: Fogyasztói magatartás trendek. KJK - Kerszöv Jogi és Üzleti Kiadó Kft, Budapest

[45] TÖRŐCSIK M., 2007: A tudatos fogyasztást és az egészséget preferáló új fogyasztói trendcsoport, a LOHAS csoport megjelenése Magyarországon, Élelmiszer, Táplálkozás és Marketing, IV. évf. 1/2007, pp 41-45

[46] TVE, 2017, Tudatos Vásárló Piaci Jelentés, http://tudatosvasarlo.hu/sites/tudatosvasarlo.hu/files/tudatos_vasarlo_piaci_jelentes_2017.pdf , Letöltés: 2017. augusztus 21.

[47] TVE, 2018: Mit jelent a tudatos vásárlás?, http://tudatosvasarlo.hu/tve/gyik, Letöltve: 2018. január 03.

[48] WEBSTER F. E., 1975: Determining the Characteristics of the Socially Conscious Consumer, The Journal of Consumer Research, Vol. 2, No. 3 (Dec., 1975), pp 188-196, http://www.jstor.org/stable/2489054?origin=JSTOR-pdf, Letöltve: 2017. december 20.

[49] WHELEER K., 2011: Change Today, Choose Fairtrade , 2011.11.04., Cultural Studies, 26:4, pp 492515, http://dx.doi.org/10.1080/09502386.2011.622780, Letöltve: 2017.03.23.

[50] ZSOLNAI L., 1998: A felelős gazdasági döntéshozatal modellje, Közgazdasági Szemle, XLV. évf., 1998. február, pp 154-162.

\section{Internetes Források}

I1: Magyar Nyelv Értelmező Szótára: „ökonómia” szócikk http://mek.oszk.hu/adatbazis/magyar-nyelv-ertelmezoszotara/kereses.php?kereses=\%C3\%B6kon\%C3\%B3mia, letöltve: 2017. július 10.

I2: Wikipédia: „oikosz” szócikk: https://hu.wikipedia.org/wiki/Oikosz, letöltve: 2017. július 10.

I3: BENTHAM J.: A Fragment on Government, 1977, Cambridge University Press, 2001, https://books.google.hu/books?id=hTSwCKh2P2UC\&pg=PR14\&lpg=PR14\&dq=quotation+becca ria + la + massima+felicita+divisa+nel+maggior+numero\&source=bl\&ots=Alq0iD93u7\&sig=98ZAy 
International Journal of Engineering and Management Sciences (IJEMS) Vol. 4. (2019). No. 3

DOI: 10.21791/IJEMS.2019.3.9.

Ssoexv0TwBYDSSNSX_tHU0\&hl=hu\&sa=X\&ved=0ahUKEwju3Zbhyo3WAhWPmLQKHXt0BvkQ6 AEIMTAC\#v=onepage\&q\&f=false, letöltve: 2017. augusztus 05. 